\title{
Acidic Deposition: Statement of World Wildlife Fund International
}

'Acid rain' (in the form of compounds of sulphur, nitrogen, hydrocarbon and allied or derived pollutants from sources such as motor vehicles, industry, and powerplants) is now a serious threat to biological communities in almost every developed country. Of particular concern are the following aspects:

1. 'Acid rain' is a major threat to Nature but need never occur at all: it is a problem that Man has added to those arising from direct use of the land and natural resources (forests, soils and oceans). Damage to flora and fauna is already unacceptably high, but the main concern should be over the indirect and potentially enormous future effect of 'acid rain' on Nature.

2. As industrialization proceeds in developing countries, 'acid rain' pollution will spread to new areas, including those of tropical forests, unless stringent control measures are adopted. Tropical forests are not only ecologically vulnerable but contain a large proportion of the world's plant and animal species. This makes them of vital concern for conservation world-wide.

3. It is now known that pollution-induced acidification of fresh waters had already been taking place for up to 100 years before it was detected and understood by scientists. In addition, forest decline has a 'latent period' of up to fifty years, during which there is little or no visible sign of damage to trees. In other words, the 'acid rain' problem may be affecting many more countries than is now realized.

4. Long-range transport of air pollutants is now reaching major ecosystems in remote areas of the world that were traditionally assumed to be free from such pollutionincluding the Arctic and Antarctic. These biologically unique areas are of great importance to scientific understanding and, as 'global commons', are an international responsibility. Measures taken to reduce the concentra- tion of pollutants in industrial areas by increased dispersion-for example using tall stacks-may lead to long-range pollution of these remote areas. Oceans can also be affected, for example by excessive runoff and atmospheric deposition of nitrogen compounds in coastal waters.

5. Acidification is destroying the value of conservation investment in establishing Nature Reserves and National Parks, and in measures taken to protect disappearing species and their habitats. This investment has taken decades to make (for example, WWF alone has spent over $\$ 100$ millions in 25 years), and has saved many species and ecological communities from destruction. The effect of 'acid rain' on both forests and fresh waters is not simply to eliminate one or two of the most prominent species: it can inhibit fundamental nutrientcycling, cause major losses of vital nutrients, interfere with primary production, and disrupt the main biological processes and relationships of an ecosystem (such as tree growth and mycorrhizas). Together with long-term changes to soil structure, this leads to elimination of the existing natural and semi-natural communities, and to the progressive destruction of biological diversity.

6. The need to persuade governments to take action on reducing polluting emissions diverts valuable staff time, resources, and effort of conservation groups, from other vital tasks such as tropical forest, wetland, and plant gene, conservation-unnecessarily, as most of those problems are soluble.

\section{Christopher Rose \\ WWF International Campaigns \& Publications Officer World Conservation Centre \\ Avenue du Mont-Blanc \\ 1196 Gland, Switzerland.}

\section{Rivers as Vital but Endangered Systems}

Dr Geoffrey Petts, in his 'Introduction to this topic' (Environmental Conservation, Vol. 12, No. 3, pp. 268 and 278,1985 ), provides an impelling indictment of river control, which has been undertaken by mankind from time immemorial with ever-increasing effects on the natural hydrological cycle.* He concludes that 'WCB and ISEE must direct themselves to safeguarding the world's natural rivers'-a view which commands wide sympathy. However, Dr Asit Biswas, in assessing 'Freshwater Trends to AD 2000', makes it clear that demands for water resources development projects, which are already great, are going to increase.

Those who write on river control and wetlands generally draw attention to the disadvantages to conservation: they rarely mention the advantages to Nature and natural resources. But the fact is that virtually every new project which is designed to conserve and use fresh water for the benefit of Mankind, also creates new wetland of considerable interest. An impoundment, for example, creates a new limnological condition near the dam, commonly with

\footnotetext{
* Most pertinently Dr Petts is about to start editing and producing, through the publishers of his recent book Impounded Rivers (reviewed by Professor Gilbert F. White on page 380 of our latest issue) in our series of Environmental Monographs \& Symposia, a new quarterly journal to be entitled Regulated Rivers: An International Journal devoted to River Research and Management, of which we hope to offer more details (over his name as Editorin-chief) in our next issue.-Ed.

$\dagger$ in our Multi-editorial commencing last year's Spring issue, on pages 2-3. - Ed.
}

swamps and delta by the inflow. All those new wetlands are rapidly colonized by flora and fauna-mostly through natural agencies, but sometimes aided by introductions. In many cases biological diversity and productivity of the area is enhanced, so that some Man-made wetlands are already designated as Nature Reserves or parts of National Parks.

In Africa alone it was stated recently (at a meeting of the new IUCN Wetlands Committee) that the area of impounded water is predicted to double between now and the end of the century. A substantial proportion of river water which is now lost to the oceans will thereby be retained as new wetlands before passing to the atmosphere through evapotranspiration or helping to recharge underground aquifers. While conservation problems in the floodplains that are affected will need close attention, so also should the diversity, adaptation, and social benefits, of the new wetlands receive it to large and enlightened extents.

The purpose of this comment is thus to sound a note of dynamic optimism to accompany the murmurs of static 'pessimism, and to express the hope that the many organizations concerned with the future well-being of The Biosphere will devote a reasonable part of their effort to new Man-made wetlands as well as making the best of those which Nature has provided.

E. Barton Worthington, CBE Colin Godmans Furners Green $\mathrm{Nr}$ Uckfield Sussex TN22 3RR England, UK. 